\section{Acetic Acid Fumigation of Apple Rootstocks and Tree Fruit Scionwood to Remove External Microflora and Potential Plant Pathogens}

\author{
Peter L. Sholberg, Paul Randall, and Cheryl R. Hampson
}

AdDitional INDEX wORDs. Erwinia amylovora, Pseudomonas syringae pv. syringae, Podosphaera leucotricha, Malus $\times$ domestica, Prunus armeniaca, Prunus persica, sterilization, vapor

Summary. Acetic acid (AA) fumigation of rootstocks and dormant shoots was explored as a method of eliminating plant pathogens from propagation material. Dormant shoots were tested in early winter to determine the rate of AA vapor that they could tolerate before being damaged. Apricot (Prunus armeniaca), apple (Malus $\times$ domestica), and peach (Prunus persica) shoots collected from a single site in Dec. 1999 tolerated 30, 12, or $6 \mathrm{mg} \cdot \mathrm{L}^{-1} \mathrm{AA}$, respectively. Vineland 3 (V3) and Malling-Merton 106 (MM.106) rootstock liners fumigated with $1 \mathrm{mg} \cdot \mathrm{L}^{-1}$ AA were adequately surface-sterilized although the effect on growth was not recorded. A similar experiment with Malling 9 (M9) rootstocks showed that $12 \mathrm{mg} \cdot \mathrm{L}^{-1}$ AA would eliminate most surface microorganisims from roots although it delayed shoot growth when the trees were planted. The higher 15 $\mathrm{mg} \cdot \mathrm{L}^{-1}$ rate delayed tree growth and appeared to kill some trees. The $12 \mathrm{mg} \cdot \mathrm{L}^{-1}$ rate prevented growth of Erwinia amylovora and Pseudomonas syringae pv. syringae bacteria on shoots even when an enrichment technique was used to detect them. Finally, when 96 'Jonagold' apple shoots known to be infected by Podosphaera leucotricha were fumigated with AA in 2001, none developed powdery mildew, although $99 \%$ of the control shoots did. These promising results suggest that further research should be done toward adapting AA fumigation for use by commercial nurseries.

$\mathrm{T}$ ree nurseries supply rootstocks, budded trees, and propagation material to fruit growers for the establishment of new orchards and the revitalization of established plantings. The material supplied by most nurseries is generally of high quality and free of disease. However, occasionally rootstocks and scionwood harbor important bacterial and fungal plant pathogens that go undetected until the rootstock is planted or the scion is budded or grafted. Diseases that have been linked to the fruit tree nursery include fire blight (Thomson, 2000), bacterial canker (Hattingh and Roos, 1995), and powdery mildew (Hickey and Yoder, 1990). Podosphaera leucotricha, the causal agent of apple powdery mildew, and Pseudomonas syringae pv. syringae, the causal agent of bacterial canker overwinter in the

Pacific Agri-Food Research Centre, Agriculture and AgriFood Canada, Summerland, BC, Canada V0H 1Z0.

We thank Trevor Shephard for technical support during the early phase of this research project. We acknowledge the Okanagan Plant Improvement Company and the matching investment initiatives fund of Agriculture and Agri-Food Canada for funding. buds of the host tree initiating disease at bud break in susceptible cultivars. P. syringae also causes dieback of M9 apple and Old Home pear (Pyrus communis) rootstocks (Sholberg and Quamme, 1999). P. syringae was also lethal to 'McIntosh' apple buds when they were artificially contaminated with the bacterium just prior to budding. Erwinia amylovora, the causal agent of fire blight, is not normally present in mature trees but is a common epiphyte (Thomson, 2000).

Acetic acid fumigation has proven to be an effective method for destroying fungal spores on fruit (Barkai-Golan,
2001; Sholberg etal., 1998), and bacterial pathogens on seed (Delaquis et al., 1999). The technique destroyed nearly all fungal microflora on cereal and oil seeds when they were fumigated with AA (Sholberg and Gaunce, 1996). For example, canola (Brassica napus) seed fumigated with $0.58 \mathrm{~mL} \cdot \mathrm{kg}^{-1}$ of seed yielded zero colonies compared to 2400 colonies in the untreated control when the seed was plated on Czapek agar. These results indicated that AA vapor could be used to sanitize other commodities that are difficult to treat with conventional sterilants. It is doubtful that any liquid sterilant would penetrate buds and roots like AA vapor and potentially kill plant pathogens.

The objectives of this study were to determine 1) what concentration of AA could be used before tissue damage would occur to scionwood of some common tree fruit cultivars; 2) the effect of AA vapor on apple rootstock microflora, especially potential root pathogens; 3 ) the effect of AA on pathogens such as E. amylovora and $P$. syringae pv. syringae that could contaminate shoots; and 4) if AA vapor would eradicate $P$. leucotricha propagules (powdery mildew) from inside buds of infected apple shoots. A preliminary report of this research has been published (Sholberg et al., 2001a).

\section{Materials and methods}

Determining BUD SURVIVAl AFTER FUMigation WITH AA. Forty-five fully dormant 'Gala' apple, 'Sundrop' apricot, and 'Red Haven' peach shoots approximately $30 \mathrm{~cm}$ in length were randomly cut from mature trees in Dec. 1999 from the Pacific Agri-food Research Centre (PARC) orchards, Summerland, B.C., Canada, and stored at $2{ }^{\circ} \mathrm{C}$.

In general AA fumigation is a relatively simple process requiring only

\begin{tabular}{llll}
\hline $\begin{array}{l}\text { Units } \\
\begin{array}{l}\text { To convert U.S. to SI, } \\
\text { multiply by }\end{array}\end{array}$ & U.S. unit & SI unit & $\begin{array}{l}\text { To convert SI to U.S., } \\
\text { multiply by }\end{array}$ \\
\hline 29.5735 & $\mathrm{fl} \mathrm{oz}$ & $\mathrm{mL}$ & 0.0338 \\
65.1985 & $\mathrm{fl} \mathrm{oz} / \mathrm{lb}$ & $\mathrm{mL} \cdot \mathrm{kg}^{-1}$ & 0.0153 \\
0.0283 & $\mathrm{ft}^{3}$ & $\mathrm{~m}^{3}$ & 35.3147 \\
3.7854 & gal & $\mathrm{L}$ & 0.2642 \\
2.5400 & inch(es) & $\mathrm{cm}$ & 0.3937 \\
25.4000 & inch(es) & $\mathrm{mm}$ & 0.0394 \\
1 & $\mathrm{ppm}$ & $\mathrm{mg} \cdot \mathrm{kg}^{-1}$ & 1 \\
1 & $\mathrm{ppm}$ & $\mathrm{mg} \cdot \mathrm{L}^{-1}$ & 1 \\
$\left({ }^{\circ} \mathrm{F}-32\right) \div 1.8$ & ${ }^{\circ} \mathrm{F}$ & ${ }^{\circ} \mathrm{C}$ & $\left(1.8 \times{ }^{\circ} \mathrm{C}\right)+32$
\end{tabular}


a closed chamber, a heater for vaporizing the acid in the chamber, and a fan to move the vapor around. In this experiment five cut shoots from each cultivar were placed in a 23 -L fumigation chamber (Sholberg et al., 2000) and fumigated at $20^{\circ} \mathrm{C}$ for $2 \mathrm{~h}$ on 31 Dec. 1999 with concentrations of 0 , 3,9 , or $12 \mathrm{mg} \cdot \mathrm{L}^{-1} \mathrm{AA}$. The remaining concentrations of $15,18,21$, or 30 $\mathrm{mg} \cdot \mathrm{L}^{-1}$ AA were applied on 17 and 18 Jan. 2000. The number of hours for each concentration of AA in parts per million were monitored in the chamber with a gas chromatograph at $0,5,10$, $15,30,60,90$, and $120 \mathrm{~min}$, following the method of Sholberg et al. (2003). Note that at standard conditions of temperature $\left(0{ }^{\circ} \mathrm{C}\right)$ and pressure [760.0 mm of mercury $(101.33 \mathrm{kPa})]$ $1 \mathrm{mg} \cdot \mathrm{L}^{-1} \mathrm{AA}$ equals $373 \mathrm{ppm}$ and at 20 ${ }^{\circ} \mathrm{C}$ it equals $400 \mathrm{ppm}$. Ppm-h defined as average AA concentration (ppm) $\times$ fumigation time $(h)$ was recorded for each fumigation. This value, also known as the CT product, describes the toxicant concentration and the amount of time it remains in contact with the target organism (Luvisi et al., 1992). The shoots were removed from the chamber shortly after each fumigation and placed, basal end first, in $500-\mathrm{mL}$ canning jars filled with distilled water. The jars were placed in a $20^{\circ} \mathrm{C}$ room where they were inspected for bud opening after approximately 1 month. Survival of flower and leaf buds was recorded separately.

EVALUATING APPLE ROOTSTOCK EXTERNAL MICROFLORA AFTER FUMIGATION WITH AA. In the first experiment $15 \mathrm{~V} 3$ and 15 MM. 106 rootstock liners were briefly washed to remove dirt and sawdust and then allowed to dry before fumigation. Tree roots were kept moist by rinsing with sterile distilled water (SDW) until fumigated. Treatments were nonfumigated control, 1 $\mathrm{mg} \cdot \mathrm{L}^{-1} \mathrm{AA}$ for $2 \mathrm{~h}$ or $10 \mathrm{mg} \cdot \mathrm{L}^{-1} \mathrm{AA}$ for $4 \mathrm{~h}$. The five single tree replicates were fumigated in a $27-\mathrm{m}^{3}$ room at $2{ }^{\circ} \mathrm{C}$ following the method used for fumigating pears (Sholberg et al., 2004). Immediately before and after fumigation two buds on each tree were swabbed with individual sterile cotton swabs. The swabs, each representing a particular tree, were placed in $10 \mathrm{~mL}$ of SDW and vortexed for $30 \mathrm{~s}$, and $1-\mathrm{mL}$ aliquots diluted $1: 1,1: 100$, or $1: 1000$ of the suspension were spread over petri plates $(50 \mathrm{~mm}$ diameter) containing $10 \mathrm{~mL}$ of lactic acid (5\% lactic acid) potato dextrose agar (LAPDA) (Difco, Detroit) or Cross and Goodman (CG) agar (Crosse and Goodman, 1973). The LAPDA was incubated at $20^{\circ} \mathrm{C}$ for $5 \mathrm{~d}$ and the $\mathrm{CG}$ was incubated at $25{ }^{\circ} \mathrm{C}$ for $8 \mathrm{~d}$ when colonies were recorded.

The second experiment involved the use of 90 M9 rootstock liners, which were fumigated in a $1-\mathrm{m}^{3} \mathrm{cham}$ ber as previously described by Sholberg et al. $(2001 \mathrm{~b})$ at a rate of 0,12 , or 15 $\mathrm{mg} \cdot \mathrm{L}^{-1}$ glacial AA for $2 \mathrm{~h}$. The experiment was repeated three times on 13 Mar., 4 Apr., and 11 Apr. with 10 trees per fumigation treatment. Acetic acid was monitored as above. Two feeder roots about $3 \mathrm{~cm}$ long were removed from each tree after fumigation, washed in SDW for $1 \mathrm{~min}$ and placed on petri plates $(10 \mathrm{~cm}$ diameter) containing $20 \mathrm{~mL}$ of LAPDA or corn meal agar (Difco). The plates were incubated at $20{ }^{\circ} \mathrm{C}$ for 3 weeks when microflora growing on or from the roots was recorded. The trees were planted in 15gal pots containing Premier Pro-Mix growing media (Premier Horticulture Ltee, Riviere-du-Loup, Que., Canada) immediately after fumigation and 1 month later were scored for growth.

EVALUATING SURVIVAL OF PLANT PATHOGENIC BACTERIA ON DORMANT SHOOTS AFTER FUMigation. Apple shoots, $30 \mathrm{~cm}$ long, were cut from 30 'Spartan' and thirty 11W-14-07 (breeding selection of unknown parentage) mature trees in Jan. 2000. The shoots from each cultivar were divided into three treatments of 10 shoots per treatment. The treatments were the noninoculated control, inoculated with $E$. amylovora (isolate 1477) or inoculated with $P$. syringae pv. syringae (isolate 980). Each suspension used for inoculation averaged 1 million CFU $/ \mathrm{mL}$. The apple shoots were inoculated by dipping the top 5 $\mathrm{cm}$ of each shoot into the appropriate bacterial suspension. The shoots were then placed upright on a Styrofoam tray and allowed to dry for $30 \mathrm{~min}$. Fifteen 'Spartan' shoots representing the three treatments were fumigated with $12 \mathrm{mg} \cdot \mathrm{L}^{-1} \mathrm{AA}$ for $2 \mathrm{~h}$ at $20^{\circ} \mathrm{C}$ in a $23-\mathrm{L}$ fumigation chamber while the remaining 15 shoots were left on the laboratory bench at $20{ }^{\circ} \mathrm{C}$. The 11W-14-07 shoots were treated similarly. After fumigation each shoot was vortexed in $10 \mathrm{~mL}$ of SDW and 0.1 $\mathrm{mL}$ of suspension was spread on each of three plates of CG or Pseudomonas
F agar (Difco). Colonies were counted on plates after 24 and $72 \mathrm{~h}$ incubation at $20^{\circ} \mathrm{C}$. The shoots were inspected for any surface damage, placed in $500-\mathrm{mL}$ canning jars filled with SDW, and the jars were incubated in the greenhouse until the buds opened about 1 month later.

Another experiment was conducted to determine if extremely low levels of E. amylovora or P. syringae pv. syringae could be detected after fumigation. Sixty dormant 'Jonagold' shoots each $30 \mathrm{~cm}$ in length were collected on 5 Mar. 2000. The shoots were inoculated and fumigated as above but only half of them were placed in $500-\mathrm{mL}$ canning jars to evaluate survival. The remaining shoots were subjected to a procedure to amplify the microflora on them. Shoots were individually trimmed to fit into test tubes containing $10 \mathrm{~mL}$ of nutrient broth (Difco) and were vortexed for $30 \mathrm{~s}$. The tubes containing these shoots were sealed for $24 \mathrm{~h}$ at $20^{\circ} \mathrm{C}$ to allow growth of potential pathogens. After $24 \mathrm{~h}$ the shoots were vortexed for $30 \mathrm{~s}$, a loopful (approximately $10 \mu \mathrm{L}$ ) of suspension was removed and streaked on CG agar plates for those shoots inoculated with E. amylovora and on Pseudomonas F agar plates for those shoots inoculated with $P$. syringae pv. syringae. Shoots that were not inoculated with either pathogen were plated on both selective agars and nutrient agar (Difco). The streaked plates were incubated at $20{ }^{\circ} \mathrm{C}$ for $48 \mathrm{~h}$ when the number of colonies was recorded.

Evaluating SURVIVAL OF POWDERY MILDEW IN APPLE BUDS AFTER FUMigation with AA. Fifty-eight and 192 white-tip 'Jonagold' shoots in Jan. 2000 and 2001, respectively, were harvested from 12 - to 13 -year-old trees in an experimental plot at PARC. The trees had not been sprayed with fungicides allowing $100 \%$ of the leaves to be infected with P. leucotricha. It was assumed that most of the new buds were also infected with $P$. leucotricha when these samples were taken. In 2000 the experiment consisted of two treatments, nonfumigated shoots and shoots fumigated in a $23-\mathrm{L}$ chamber with $12 \mathrm{mg} \cdot \mathrm{L}^{-1} \mathrm{AA}$ at $20^{\circ} \mathrm{C}$ for $2 \mathrm{~h}$. The treatments were replicated twice with fumigations on 22 and $24 \mathrm{Feb} .2000$. In 2001 the experiment consisted of three treatments, nonfumigated, 9 $\mathrm{mg} \cdot \mathrm{L}^{-1}, 12 \mathrm{mg} \cdot \mathrm{L}^{-1}$ AA with a nonfumigated control for each rate. The trial 
was repeated twice in late January with each replicate consisting of 24 whitetip shoots. After fumigation the shoots were placed in canning jars containing $500 \mathrm{~mL} \mathrm{SDW}$ and incubated in the greenhouse for 4 weeks when number of shoots with powdery mildew were recorded.

Statistical analysis. Data from fumigation experiments were statistically analyzed by the General Linear Models or TTest procedures (SAS Institute, Cary, N.C.) and where appropriate means were separated according to the Waller-Duncan $k$-ratio t-test where $k=100$ (approximately $P$ $\leq 0.05$ ) or least significant difference test $(P \leq 0.05)$. Graphical data was presented with the aid of Sigma Plot 2002 for Windows software (version 8.02; Systat Software Inc., Richmond, Calif.).

\section{Results and discussion}

BUD SURVIVAL ON DORMANT SCIONWOOD AFTER FUMIGATION WITH AA. Apple and apricot leaf buds were much more tolerant of AA vapor than peach leaf buds (Fig. 1). None of the peach leaf or flower buds survived concentrations greater than $6 \mathrm{mg} \cdot \mathrm{L}^{-1}$ showing signs of browning and desiccation at higher rates. Apple leaf buds tolerated much higher rates and appeared to have the same viability over the range from 0 to $12 \mathrm{mg} \cdot \mathrm{L}^{-1}$. Apricot flower and leaf buds were much more tolerant than either apples or peaches having an average of four buds per shoot surviving 30 $\mathrm{mg} \cdot \mathrm{L}^{-1}$ rate which was the highest rate used in this experiment. The relationship between AA rate to ppm-h during fumigation of these shoots was linear (Fig. 2) corresponding to increased toxicity with higher AA concentrations. $\mathrm{Ppm}-\mathrm{h}$ is considered a better way of describing crop fumigation because it includes time as well as concentration. These results on buds indicate that differences in tolerance to AA exist among fruit crops. This could relate to whether the bud structure is open to air or if it is tightly closed when the shoots are fumigated. The rates necessary to kill most plant pathogens range from 2 to $4 \mathrm{mg} \cdot \mathrm{L}^{-1} \mathrm{AA}$ (Sholberg et al., 1998) and are therefore lower than the rate that damaged the most sensitive dormant host shoot at $9 \mathrm{mg} \cdot \mathrm{L}^{-1}$ in this limited trial.

Microflora ON ROOTSTOCK SURFACES AFTER FUMIGATION WITH AA. In a preliminary trial to test AA

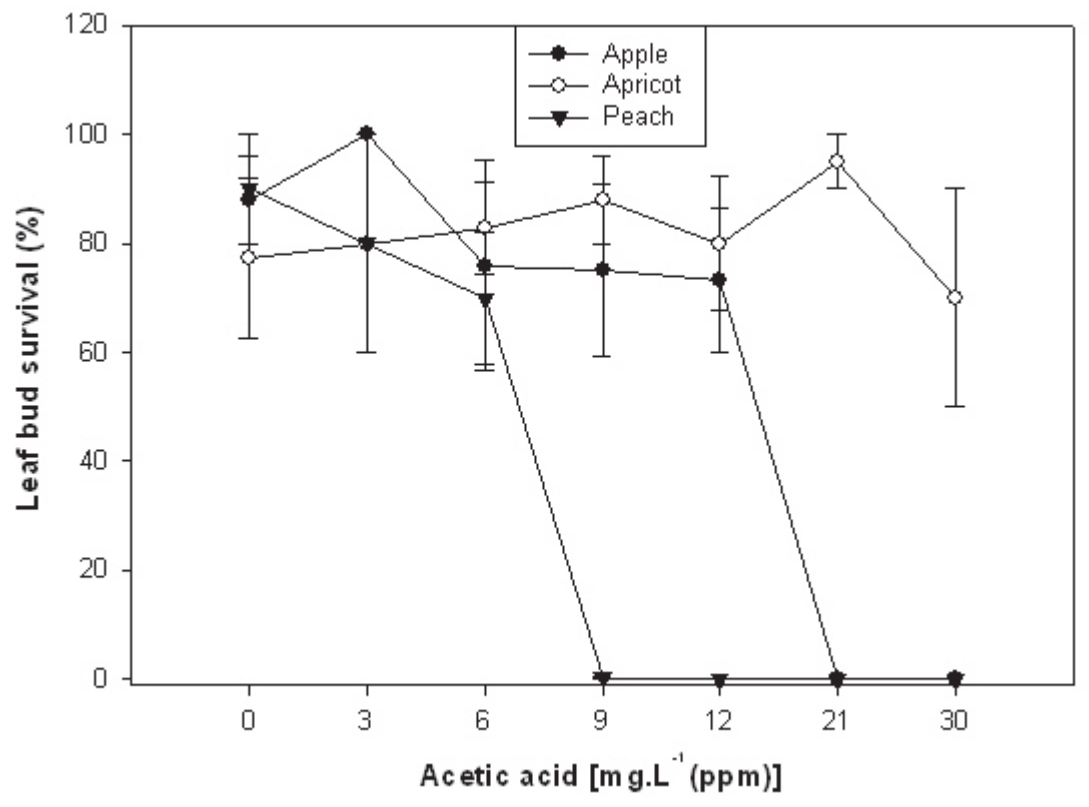

Fig. 1. Mean percent bud survival of apple, apricot, or peach leaf buds on dormant scionwood when fumigated with 0 to $30 \mathrm{mg} \cdot \mathrm{L}^{-1}(\mathrm{ppm})$ acetic acid (AA) vapor. Shoots $30 \mathrm{~cm}(11.8$ inches $)$ in length were fumigated at $20{ }^{\circ} \mathrm{C}\left(68.0{ }^{\circ} \mathrm{F}\right)$ for $2 \mathrm{~h}$, placed basal end first into jars containing $500 \mathrm{~mL}(16.9 \mathrm{fl} \mathrm{oz})$ of sterile distilled water (SDW), and leaf bud growth was recorded approximately one month after incubation in a $20^{\circ} \mathrm{C}$ room. Vertical bars represent mean \pm SE for five replications.

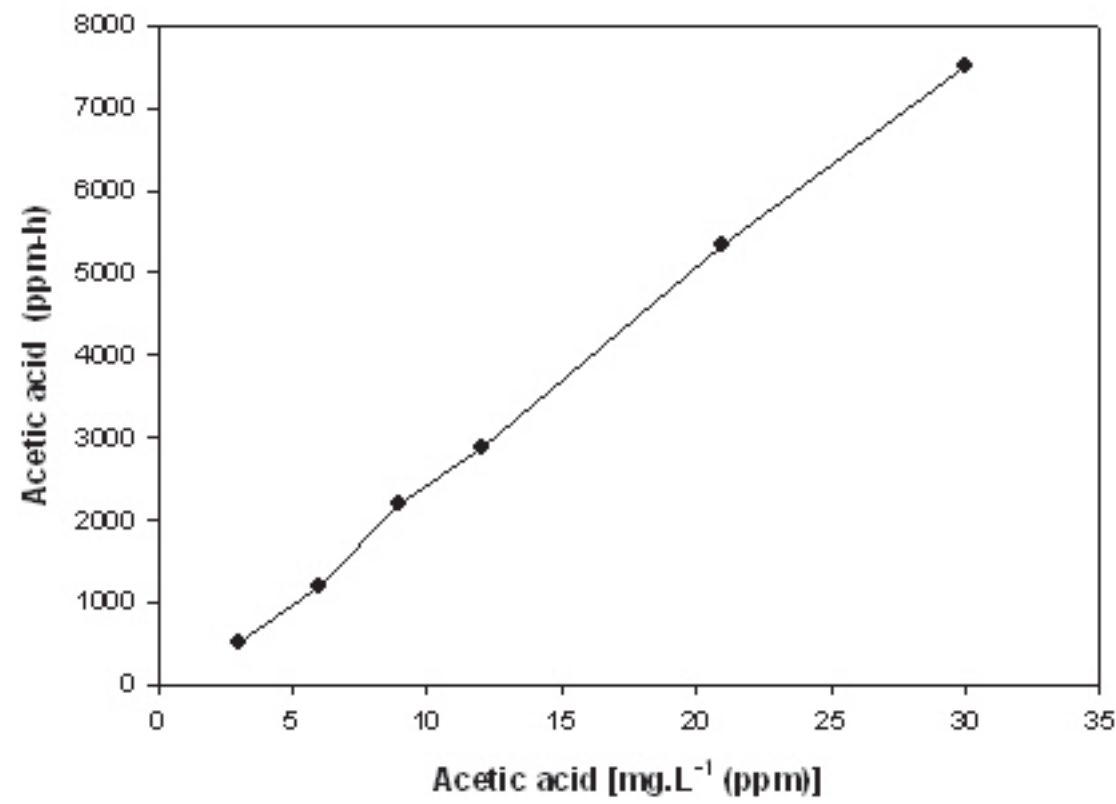

Fig. 2. Relationship of acetic acid (AA) rate in $\mathrm{mg} \cdot \mathrm{L}^{-1}(\mathrm{ppm})$ weight by volume to $\mathrm{ppm}-\mathrm{h}\left(\mathrm{g} \cdot \mathrm{m}^{-3} \times(24 \mathrm{~L} / 60.05 \mathrm{~g}) \times 1000 / \mathrm{h}\right)$ volume by volume during fumigation of fruit tree shoots in a $23-\mathrm{L}(6.1 \mathrm{gal})$ chamber over the concentration range of 0 to $30 \mathrm{mg} \cdot \mathrm{L}^{-1} \mathrm{AA}$. The fumigation duration was $2 \mathrm{~h}$ at $20^{\circ} \mathrm{C}\left(68.0{ }^{\circ} \mathrm{F}\right) ; \mathrm{l}$ ppm weight by volume $\mathrm{AA}=400 \mathrm{ppm}$ volume by volume $\mathrm{AA}$ at $20^{\circ} \mathrm{C}$.

fumigation of complete trees, it was found that $1 \mathrm{mg} \cdot \mathrm{L}^{-1}$ removed all the culturable epiphytic yeast and most of the epiphytic mold (Penicillium spp., Mucor spp., Botrytis spp., and white mycelium) from the bud surface of
V3 and MM.106 rootstocks (Table 1 ). The higher rate of $10 \mathrm{mg} \cdot \mathrm{L}^{-1} \mathrm{AA}$ did not appear to be necessary for removal of surface molds. Unfortunately, the presence of molds in roots was not studied and the viability of these trees 
Table 1. Effect of acetic acid (AA) fumigation on surface microflora of Vineland 3 (V3) or Malling-Merton (MM106) apple rootstock buds

\begin{tabular}{|c|c|c|c|c|}
\hline \multirow{2}{*}{$\begin{array}{l}\mathrm{AA}\left[\mathrm{mg} \cdot \mathrm{L}^{-1}\right. \\
(\mathrm{ppm})\left[^{\mathrm{x}}\right.\end{array}$} & \multicolumn{2}{|c|}{$\begin{array}{l}\text { V3 rootstock bud microflora } \\
(\mathrm{CFU} / \mathrm{mL})^{\mathrm{y}}\end{array}$} & \multicolumn{2}{|c|}{$\begin{array}{l}\text { MM106 rootstock bud microfora } \\
(\mathrm{CFU} / \mathrm{mL})^{\mathrm{y}}\end{array}$} \\
\hline & Mold & Yeast & Mold & Yeast \\
\hline 0 & $64 a^{z}$ & $1594 \mathrm{a}$ & $164 \mathrm{a}$ & $1264 \mathrm{a}$ \\
\hline 1 & $0.8 \mathrm{~b}$ & $0 \mathrm{~b}$ & $0 \mathrm{a}$ & $1 \mathrm{~b}$ \\
\hline 10 & $0.2 \mathrm{~b}$ & $0 \mathrm{~b}$ & $0 \mathrm{a}$ & $0 \mathrm{~b}$ \\
\hline$P>\mathrm{F}$ & 0.0136 & $<0.0001$ & 0.0844 & 0.0001 \\
\hline
\end{tabular}

${ }^{2}$ Five V3 or MM106 rootstock single tree replicates were used for each treatment.

Two buds per rootstock were swabbed with sterile cotton swabs. The swabs were placed in test-tubes containing $10 \mathrm{~mL}(0.3 \mathrm{fl} \mathrm{oz})$ of sterile distilled water, and vortexed for $30 \mathrm{~s}$. One $\mathrm{mL}(0.03 \mathrm{fl} \mathrm{oz})$ of this wash water diluted 1:1, 1:100, or 1:1000 was spread over lactic acid potato dextrose agar or Crosse and Goodman agar in 10.0- $\mathrm{cm}-$ diameter $\left(3.94\right.$ inches ) petri plates, and incubated at $20^{\circ} \mathrm{C}\left(68.0^{\circ} \mathrm{F}\right)$ or $25^{\circ} \mathrm{C}\left(77.0^{\circ} \mathrm{F}\right)$ for 5 or $8 \mathrm{~d}$, respectively; $\mathrm{l} \mathrm{CFU} / \mathrm{mL}=29.5735 \mathrm{CFU} / \mathrm{fl} \mathrm{oz}$.

'Values with the same letter are not significantly different according to the Waller-Duncan k-ratio t-test $(\mathrm{k}=100$ or approximately $P \leq 0.05$ ) for mean separation.

Table 2. Effect of acetic acid (AA) fumigation on Malling 9 (M9) apple root surface microflora, shoot length after 2 months, and tree growth after 4 months.

\begin{tabular}{|c|c|c|c|c|c|c|}
\hline \multirow{2}{*}{$\begin{array}{l}\text { AA } \\
{\left[\mathrm{mg} \cdot \mathrm{L}^{-1}\right.} \\
\underline{(\mathrm{ppm})]^{\mathrm{x}}}\end{array}$} & \multicolumn{2}{|c|}{ Infested roots $(\%)^{\mathrm{z}}$} & \multirow{2}{*}{$\begin{array}{l}\text { Shoot } \\
\text { length } \\
(\mathrm{cm})^{\mathrm{w}}\end{array}$} & \multicolumn{3}{|c|}{ Tree growth $(\%)^{y}$} \\
\hline & LAPDA & CMA & & Normal & Delayed & Dead \\
\hline 0 & $100.0 \mathrm{a}^{\mathrm{v}}$ & $73.3 \mathrm{a}$ & $23.8 \mathrm{a}$ & $96.7 \mathrm{a}$ & $3.3 \mathrm{~b}$ & $0.0 \mathrm{a}$ \\
\hline 12 & $6.7 \mathrm{~b}$ & $13.3 \mathrm{~b}$ & $12.7 \mathrm{~b}$ & $66.7 \mathrm{ab}$ & $30.0 \mathrm{ab}$ & $3.3 \mathrm{a}$ \\
\hline 15 & $0.0 \mathrm{~b}$ & $6.7 \mathrm{~b}$ & $6.5 \mathrm{c}$ & $36.7 \mathrm{~b}$ & $46.7 \mathrm{a}$ & $16.7 \mathrm{a}$ \\
\hline$P>\mathrm{F}$ & $<0.0001$ & 0.0325 & $<0.0001$ & 0.0217 & 0.0356 & 0.1736 \\
\hline
\end{tabular}

${ }^{2}$ Two feeder roots, each approximately $3 \mathrm{~cm}$ ( 1.2 inches $)$ in length, were removed from each tree, washed in steriledistilled water for about $1 \mathrm{~min}$. Two root cuttings were placed on three lactic acid potato dextrose agar (LAPDA) or three corn meal agar (CMA) plates $10.0 \mathrm{~cm}$ (3.94 inches) in diameter and incubated at $20{ }^{\circ} \mathrm{C}$ for 2 weeks. ${ }^{y}$ Effect of AA fumigation on growth of M9 trees was evaluated by measuring average length of shoots on each tree 2 months after fumigation, and judging tree appearance as normal or abnormal compared to the control.

${ }^{x}$ Rate of AA used to fumigate $10 \mathrm{M} 9$ rootstocks in a $1-\mathrm{m}^{3}\left(35.3 \mathrm{ft}^{3}\right)$ chamber for $2 \mathrm{~h}$ at $20{ }^{\circ} \mathrm{C}\left(68.0{ }^{\circ} \mathrm{F}\right)$. The experiment was replicated three times.

w $1 \mathrm{~cm}=0.3937$ inch

"Values with the same letter in columns are not significantly different according to the Waller-Duncan k-ratio t-test ( $\mathrm{k}=100$ or approximately $P \leq 0.05$ ) for mean separation.

was not evaluated. A second more extensive experiment on $\mathrm{M} 9$ rootstocks showed that AA fumigation at 12 and $15 \mathrm{mg} \cdot \mathrm{L}^{-1}$ significantly reduced mold growth from feeder roots (Table 2 ). In fact the $15 \mathrm{mg} \cdot \mathrm{L}^{-1}$ rate reduced the number of feeder roots with mold to zero when LAPDA was used to monitor mold infection. The $12 \mathrm{mg} \cdot \mathrm{L}^{-1}$ rate significantly reduced shoot growth compared to the control trees when measured 2 months after fumigation but by 4 months the difference between them was becoming much less noticeable and eventually treated trees were the same in all aspects of growth as control trees. The $15 \mathrm{mg} \cdot \mathrm{L}^{-1}$ rate was very effective on mold but delayed growth in almost half of the trees and killed $17 \%$ of them. Based on these results, rates over $12 \mathrm{mg} \cdot \mathrm{L}^{-1} \mathrm{AA}$ should not be used on dormant trees with exposed roots. Furthermore, results could be different if the fumigated trees were held for a lengthly period after treatment and before planting. More research will be needed before AA can freely be used without concern for plant damage.

Plant pathogenic bacteria on DORMANT SHOOTS AFTER FUMIGATION. Fumigation of shoots with $12 \mathrm{mg} \cdot \mathrm{L}^{-1}$ AA vapor that were artificially contaminated with $P$. syringae pv. syringae reduced colony counts from many thousands on the untreated shoots to almost zero for fumigated shoots (Table 3). The treatment did not appear to have any adverse effect on bud opening of 11W-14-07 or 'Spartan' that had been inoculated with E. amylovora or $P$. syringae pv. syringae. Fumigation appeared to improve bud opening in control buds and 'Spartan' buds inoculated with $P$. syringae pv. syringae. P. syringae pv. syringae is thought to overwinter in dormant buds, but usually is not pathogenic to pome fruit buds (Mansvelt and Hattingh, 1987). Apple blister bark or pear blossom blast caused by P. syringae pv. syringae likely develops from symptomless buds from infected trees that are grafted onto rootstocks in new plantings.

AA fumigation almost eliminated E. amylovora from both $11 \mathrm{~W}-14-07$ and 'Spartan' apple shoots (Table 3). E. amylovora may live for long periods as a resident in or on apparently healthy pear and apple tissues (van der Zwet and Beer, 1995).

This could be an important treatment where fire blight is known to occur in the vicinity of the nursery.

There was concern that we may have not detected all the bacteria on the shoots using the above detection method so another method was used to amplify epiphytic bacteria. 'Jonagold'

Table 3. Survival of microflora on dormant 'Spartan' or 11W-14-07 apple shoots inoculated with Erwinia amylovora or Pseudomonas syringae pv. syringae and percent open leaf buds on shoots fumigated with acetic acid (AA).

\begin{tabular}{|c|c|c|c|c|c|c|c|}
\hline \multirow{2}{*}{$\begin{array}{l}\mathrm{AA}\left[\mathrm{mg} \cdot \mathrm{L}^{-1}\right. \\
(\mathrm{ppm})]^{\mathrm{z}}\end{array}$} & \multirow[b]{2}{*}{ Cultivar } & \multicolumn{3}{|c|}{$\mathrm{CFU} / \mathrm{mL}$} & \multicolumn{3}{|c|}{ Leaf buds (\%) } \\
\hline & & Control & $\mathrm{Ea}^{\mathrm{y}}$ & Pss $^{x}$ & Control & Ea & Pss \\
\hline 0 & $11 \mathrm{~W}-14$ & $194 a^{w}$ & $43704 \mathrm{a}$ & $5020 \mathrm{a}$ & $45.2 \mathrm{a}$ & $81.6 \mathrm{a}$ & $77.4 \mathrm{a}$ \\
\hline$P>\mathrm{F}$ & & 0.0195 & 0.0477 & 0.0676 & 0.2041 & 0.5136 & 0.5912 \\
\hline 0 & Spartan & $1279 \mathrm{a}$ & $394060 \mathrm{a}$ & 38621 a & $79.2 \mathrm{a}$ & $82.4 \mathrm{a}$ & $83.6 \mathrm{a}$ \\
\hline 12 & Spartan & $11 \mathrm{~b}$ & $17 \mathrm{~b}$ & $56 \mathrm{~b}$ & $89.0 \mathrm{a}$ & $80.0 \mathrm{a}$ & $85.4 \mathrm{a}$ \\
\hline
\end{tabular}

${ }^{2}$ Rate of AA used to fumigate $30 \mathrm{~cm}$ (11.8 inches) long shoots of 'Spartan' or $11 \mathrm{~W}-14-07$ replicated five times in a $23-\mathrm{L}(6.1 \mathrm{gal}) \mathrm{chamber}$ for $2 \mathrm{~h}$ at $20{ }^{\circ} \mathrm{C}\left(68.0{ }^{\circ} \mathrm{F}\right)$.

${ }^{y}$ E. amylovora bacterial suspension $(1$ million $\mathrm{CFU} / \mathrm{mL}$ ) used to inoculate dormant scionwood; $1 \mathrm{CFU} / \mathrm{mL}=29.5735 \mathrm{CFU} / \mathrm{fl} \mathrm{oz}$.

'Ps. syringae pv. syringae bacterial suspension ( 1 million $\mathrm{CFU} / \mathrm{mL}$ ) used to inoculate dormant scionwood.

"Means followed by the same letter in a column are not significantly different (Fisher's least significant difference test, $P>0.05$ ) 
Table 4. Effect of acetic acid (AA) fumigation on number of microorganisms recovered from 'Jonagold' shoots inoculated with E. amylovora or P. syringae after enrichment in nutrient broth and the effect of AA on 'Jonagold' bud opening.

\begin{tabular}{|c|c|c|c|c|c|}
\hline \multirow{2}{*}{$\begin{array}{l}\mathrm{AA} \\
{\left[\mathrm{mg} \cdot \mathrm{L}^{-1}\right.} \\
(\mathrm{ppm})]^{\mathrm{z}}\end{array}$} & \multirow[b]{2}{*}{ Inoculum } & \multicolumn{3}{|c|}{$\begin{array}{c}\text { Microorganisms recovered } \\
\text { by enrichment }\end{array}$} & \multirow{2}{*}{$\begin{array}{c}\text { No. shoots with } \\
\text { open buds } \\
\text { out of } 5\end{array}$} \\
\hline & & CG & PsF & NA & \\
\hline 0 & None & Fungus sp. & +++ & +++ & 5 \\
\hline 12 & None & 0 & Bacillus spp. & 0 & 5 \\
\hline 0 & E. amylovora & $+++^{x}$ & nd & nd & 5 \\
\hline 12 & E. amylovora & 0 & nd & nd & 5 \\
\hline 0 & P. syringae & $\mathrm{nd}^{\mathrm{w}}$ & +++ & nd & 5 \\
\hline 12 & P. syringae & nd & 0 & nd & 5 \\
\hline
\end{tabular}

z'Jonagold' apple shoots were inoculated by dipping $5 \mathrm{~cm}(2.0$ inches $)$ shoot lengths into a $10 \mathrm{~mL}(0.3 \mathrm{fl} \mathrm{oz})$ suspension of bacteria containing 10 million CFU $/ \mathrm{mL}(1 \mathrm{CFU} / \mathrm{mL}=29.5735 \mathrm{CFU} / \mathrm{fl} \mathrm{oz})$

yAfter fumigation the shoots were immersed in $10 \mathrm{~mL}$ of nutrient broth for $24 \mathrm{~h}$ at $20^{\circ} \mathrm{C}\left(68.0^{\circ} \mathrm{F}\right)$. One loopful of broth (approximately $10 \mathrm{uL}$ ) was then streaked on Crosse and Goodman (CG) agar, Pseudomonas F (PsF) agar, and nutrient agar (NA) and the plates were incubated at $20^{\circ} \mathrm{C}$ for $48 \mathrm{~h}$ when the plates were checked for growth. $\mathrm{x}_{+++}=$numerous colonies of yeast, bacteria, or fungi.

wnd $=$ no data.

apple shoots fumigated and subjected to bacterial enrichment did not have any E. amylovora or P. syringae pv. syringae on their surfaces in this test (Table 4 ). Fumigation with AA at the $12 \mathrm{mg} \cdot \mathrm{L}^{-1}$ rate was very effective in removing all microorganisms from the shoot surfaces whether inoculated or naturally occurring microflora. The only bacteria that survived fumigation were a few Bacillus spp. based on their distinctive colony appearance. This is understandable because Bacillus endospores are far more resistant to destruction by disinfecting chemicals than are the cells of most bacteria (Sneath, 1986).

SURVIVAL OF POWDERY MILDEW IN APPLE BUDS AFTER FUMIGATION WITH AA. Shoots of 'Jonagold' that were fumigated with $12 \mathrm{mg} \cdot \mathrm{L}^{-1}$ AA vapor for $2 \mathrm{~h}$ at $20^{\circ} \mathrm{C}$ in 2000 were rendered free of powdery mildew infection although the nonfumigated shoots from the same trees were all infected (Table 5 ). The treatment did not appear to damage the shoots and was repeated in 2001 with 9 or $12 \mathrm{mg} \cdot \mathrm{L}^{-1} \mathrm{AA}$ with the same results indicating that the lower rate of $9 \mathrm{mg} \cdot \mathrm{L}^{-1} \mathrm{AA}$ is also effective. AA vapor appears to penetrate between the bud scales killing all living propagules of Podosphaera leucotricha. Burchill (1960) eradicated mildew in apple bud with 4,6-dinitro-o-cresol (DNOC) in $3 \%$ petroleum oil. Eradication also has been achieved with dormant sprays containing methyl esters of fatty acids or other surface active compounds (Ogawa and English, 1991). However this is the first case to our knowledge where a fumigant has been used for eradication of powdery mildew in buds. AA vapor at the rates used in this experiment was not phytotoxic to dormant apple shoots infected with powdery mildew. The treatment does not appear to be suitable for use in the orchard although a tent made of polyethylene could be considered for use as a fumigation chamber. The treatment could be practical in the nursery for the fumigation of shoots used as scionwood to prevent spread of powdery mildew to disease free areas and possibly on small trees that could be infected with P. leucotricha.

AA has an oral $\mathrm{LD}_{50}$ of 3310 $\mathrm{mg} \cdot \mathrm{kg}^{-1}$ according to its Material Safety data sheet (Fisher Scientific, Nepean, Ont., Canada) that shows it is not particularly toxic to mammals. This is not surprising because as vinegar it is eaten in large quantities in products such as pickles. Pure glacial AA has a flashpoint of $39^{\circ} \mathrm{C}$ and a lower explosive limit at $59^{\circ} \mathrm{C}$ when it forms $4.0 \%$ of the air. Normally we would not expect to see this concentration of AA in air when fumigating propagation material except during the early stages of evaporation of AA before it is mixed with air. Probably the two biggest concerns with the use of AA are inhalation of over $1000 \mathrm{ppm}$ of the pure vapor or splashing glacial AA into the eyes. Safety glasses and an appropriate respirator should always be used when handling this material.

In conclusion, AA fumigation of nursery stock is an effective practice for eradication of several potential pathogens from bark surfaces, roots, and buds of trees used for propagation. The treatment is not registered at this time and the rates examined in this study are experimental and will need further testing. Phytotoxicity is the main concern with AA fumiga-
Table 5. Effect of acetic acid (AA) fumigation on percent powdery mildew (Podosphaera leucotricha) infection of dormant 'Jonagold' apple shoots in 2000 and 2001.

\begin{tabular}{l}
\hline Treatment \\
\cline { 2 - 3 } powdery mildew (\%)
\end{tabular}

tion of nursery stock and care must be taken to make sure that the trees are fully dormant and rates are kept as low as possible. Finally, care must be taken to avoid water condensation on the propagation material when fumigating because AA vapor will be absorbed by water droplets that will burn plant tissue.

\section{Literature cited}

Barkai-Golan, R. 2001. Postharvest diseases of fruits and vegetables: Development and control. Elsevier, New York.

Burchill, R.T. 1960. The role of secondary infections in spread of apple powdery mildew Podosphaera leucotricha (Ell. \& Ev.) Salm. J. Hort. Sci. 35:66-72.

Crosse, J.E. and R.N. Goodman. 1973. A selective medium for and a definitive colony characteristic of Erwinia amylovora. Phytopathology 63:1425-1426.

Delaquis, P.J., P.L. Sholberg, and K. Stanich. 1999. Disinfection of mung bean seed with gaseous acetic acid. J. Food Protection 62:953-957.

Hattingh, M.J. and I.M.M. Roos. 1995. Bacterial canker, p. 48-50. In: J.M. Ogawa, E.I.Zehr, G.W. Bird, D.F. Ritchie, K. Uriu, and J.K. Uyemoto. Compendium of stone fruit diseases. APS Press, St. Paul, Minn.

Hickey, K.D. and K.S. Yoder. 1990. Powdery mildew, p. 9-10. In: A.L. Jones and H.S. Aldwinckle (eds.). Compendium of apple and pear diseases. APS Press, St. Paul, Minn.

Luvisi, D.A., H.H. Shorey, J.L. Smilanick, J.F. Thompson, B.H. Gump, and J. Knutson. 1992. Sulfur dioxide fumigation of 
table grapes. Univ. of California, Div. Agr. and Natural Resources, Bul. 1932

Mansvelt, E.L. and M.J. Hattingh. 1987. Pseudomonas syringae pv. syringae associated with apple and pear buds in South Africa. Plant Dis. 71:789-792.

Ogawa, J.M. and H. English. 1991. Diseases of temperate zone tree fruit and nut crops. Univ. of California, Div. Agr. and Natural Resources, Publ. 3345.

Sholberg, P.L., M. Cliff, and A.L. Moyls. 2001 b. Fumigation with acetic acid vapor to control decay of stored apples. Fruits 56:355-366.

Sholberg, P.L., P.J. Delaquis, and A.L. Moyls. 1998. Use of acetic acid fumigation to reduce the potential for decay in harvested crops. Recent Res. Dev. Plant Pathol. 2:31-4l.

Sholberg, P.L. and A.P. Gaunce. 1996. Fumigation of high moisture seed with acetic acid to control storage mold. Can. J. Plant Sci. 76:551-555.

Sholberg, P., P. Haag, R. Hocking, and K. Bedford. 2000. The use of vinegar vapor to reduce postharvest decay of harvested fruit. HortScience 35:898-203.

Sholberg, P.L. and H.A. Quamme. 1999. Dieback of pome fruit rootstocks caused by Pseudomonas syringae. Can. J. Plant Sci. 79:387-394.

Sholberg, P., P. Randall, C. Hampson, and T. Shephard. 2001a. Fumigation of dormant scion wood with acetic acid vapor to eliminate microbial contamination. HortScience 36:555 (Abstr.).

Sholberg, P., T. Shephard, and L. Moyls. 2003. Monitoring acetic acid vapor concentrations during fumigation of fruit for control of post harvest decay. Can. Biosystems Eng. 45:3.13-3.17.

Sholberg, P.L., T. Shephard, P. Randall, and L. Moyls. 2004. Use of measured concentrations of acetic acid vapor to control postharvest decay in d'Anjou pears. Postharvest Biol. Technol. 32:89-98.

Sneath, P.H.A. 1986. Endospore-forming gram-positive rods and cocci, $\mathrm{p}$. 1104-1127. In: P.H. Sneath (ed.). Bergey's manual of systematic bacteriology. Williams \& Wilkins, Philadelphia.

Thomson, S.V. 2000. Epidemiology of fire blight, p.9-36. In: J.L. Vanneste (ed.). Fire blight: The disease and its causative agent. CABI Publ., Oxon, U.K.

van der Zwet, T. and S.V. Beer. 1995. Fire blight-Its nature, prevention, and control: A practical guide to integrated disease management. U.S. Dept. Agr., Agr. Info. Bul. No. 631. 